\title{
Тетяна КІЗИМА
}

доктор економічних наук, профресор, Тернопільський національний економічний університет, Тернопіль, Україна, tetyana.kizyma68@gmail.com

ORCID ID: 0000-0002-9732-9907

\section{Ірина КРУП'ЯК}

кандидат економічних наук, доцент, Тернопільський національний економічний

університет, Тернопіль, Україна, i.krupyak@tneu.edu.ua

ORCID ID: 0000-0001-5618-4863

\section{Наталія КОЛОМИЙчУК}

кандидат економічних наук, доцент, Тернопільський національний економічний університет, Тернопіль, Україна, n.kolomyichuk@tneu.edu.ua

ORCID ID: 0000-0001-6160-9053

\section{МЕТОДИКА ВИКААДАННЯ ФІНАНСОВОЇ ГРАМОТНОСТI У ВИЩІЙ ШКОАІ: ДОСВІД ТА ПЕРСПЕКТИВИ}

Вступ. Невід’ємною умовою детермінування ролі освітніх чинників у процесі формування фрінансового світогляду громадян $є$ розроблення й апробація ефективної та дієвої методики викладання фрінансової грамотності. Водночас нині відсутній єдиний методичний підхід щодо викладання фрінансової грамотності у закладах освіти України, що потребує активізації наукових зусиль, спрямованих на дослідження вищеозначеної проблеми.

Мета - систематизувати досвід викладання фрінансової грамотності у вищій школі та виокремити перспективи його удосконалення в сучасних умовах розвитку українського освітянського простору.

Методи. У дослідженні використано методи діалектичного аналізу та синтезу, а також логічного узагальнення, порівняння і формалізації.

Результати. Досліджено новітні методи викладання фрінансової грамотності, виокремлено особливості і переваги кожного з них та наголошено на позитивних ефектах, які вони спричиняють, а саме: сприяння розвитку теоретичного мислення та пізнавального інтересу до фрінансової грамотності; активізація сприйняття матеріалу в прочесі викладання основ фрінансової грамотності; забезпечення профресійної мотивації та фрормування корпоративної культури у студентів в процесі вивчення дисципліни “Методика викладання фрінансової грамотності". Проаналізовано низку науково-педагогічних заходів, організованих і проведених у Тернопільському національному економічному університеті спільно з педагогами загальноосвітніх, професійних та вищих навчальних закладів з метою обговорення векторів удосконалення чинної методики ви-

(c) Тетяна Олексіївна Кізима, Ірина Йосипівна Круп'як, Наталія Михайлівна Коломийчук, 2020 
кладання фрінансової грамотності. Обгрунтовано необхідність використання інноваційних інструментів у процесі викладання фрінансової грамотності у вітчизняних закладах освіти та запропоновано напрями підвищення рівня фрінансової грамотності українців у сучасних умовах.

Перспективи. В подальщих наукових дослідженнях пропонується зосередити увагу на виокремленні основних векторів підвищення рівня фрінансової грамотності дітей та молоді, як найбільш потенційно сприятливих для цього верств українського суспільства. На нашу думку, це дасть можливість сорормувати цілісну систему заходів для подолання інколи байдужого ставлення молоді до свого майбутнього фрінансового благополуччя.

Ключові слова: фрінансова грамотність, методика викладання фрінансової грамотності, кейс-метод, тренінг, ділова гра, проблемна лекція, лекція-візуалізація, бінарна лекція, лекція із заздалегідь запланованими помилками, лекція-пресконференція.

Бібл.: 8.

\section{Татьяна КИЗЫМА}

доктор экономических наук, профрессор, Тернопольский национальный экономический университет, Тернополь, Украина

\section{Ирина КРУПЬЯк}

кандидат экономических наук, доцент, Тернопольский национальный экономический университет, Тернополь, Украина

\section{Наталия КОлОМИЙчУк}

кандидат экономических наук, доцент, Тернопольский национальный экономический университет, Тернополь, Украина

\section{МЕТОДИКА ПРЕПОДАВАНИЯ ФИНАНСОВОЙ ГРАМОТНОСТИ В ВЫСШЕЙ ШКОАЕ: ОПЫТ И ПЕРСПЕКТИВЫ}

Введение. Неотъемлемым условием детерминирования роли образовательных фракторов в процессе формирования фринансового мировоззрения граждан являются разработка и апробация эффрективной и действенной методики преподавания финансовой грамотности. В то же время сейчас отсутствует единый методический подход к преподаванию фринансовой грамотности в учебных заведениях Украины, что требует активизации научных усилий, направленных на исследование вышеназванной проблемы.

Цель - систематизировать опыт преподавания фринансовой грамотности в высшей школе и выделить перспективы его совершенствования в современных условиях развития отечественного образовательного пространства.

Методы. В исследовании использованы методы диалектического анализа и синтеза, а также логического обобщения, сравнения и фрормализации.

Результаты. Исследованы инновационные методы преподавания фринансовой грамотности, выделены особенности и преимущества каждого из них и отмечены позитивные эффректы, которые они вызывают, а именно: содействие развитию теоретического мышления и познавательного интереса к финансовой грамотности; активизация восприятия материала в процессе преподавания основ фринансовой грамотности; обеспечение профессиональной мотивации и формирование корпоративной 
культуры у студентов при изучении дисциплины “Методика преподавания фринансовой грамотности”. Проанализирован ряд научно-педагогических мероприятий, организованных и проведенных в Тернопольском национальном экономическом университете совместно с педагогами общеобразовательных, профессиональных и высших учебных заведений с целью обсуждения векторов совершенствования действующей методики преподавания финансовой грамотности. Обоснована необходимость использования инновационных инструментов при преподавании фринансовой грамотности в отечественных учебных заведениях и предложены направления повышения уровня фринансовой грамотности украинцев в современных условиях.

Перспективы. В дальнейших научных исследованиях предлагается сосредоточить внимание на выделении основных векторов повышения уровня финансовой грамотности детей и молодежи, как наиболее потенциально благоприятных для этого слоев украинского общества. По нашему мнению, это даст возможность сфрормировать целостную систему мер по преодолению иногда безразличного отношения молодежи к своему будущему финансовому благополучию.

Ключевые слова: финансовая грамотность, методика преподавания фринансовой грамотности, кейс-метод, тренинг, деловая игра, проблемная лекция, лекция-визуализация, бинарная лекция, лекция с заранее запланированными ошибками, лекция-прессконфреренция.

\section{Tetiana KIZYMA}

Dr. Sc. (Economics), Prof., Ternopil National Economic University, Ternopil, Ukraine, tetyana.kizyma68@gmail.com

ORCID ID: 0000-0002-9732-9907

\section{Iryna KRUPIAK}

Ph. D. (Economics), Assoc. Prof., Ternopil National Economic University, Ternopil, Ukraine, i.krupyak@tneu.edu.ua

ORCID ID: 0000-0001-5618-4863

\section{Natalia KOLOMYYCHUK}

Ph. D. (Economics), Assoc. Prof., Ternopil National Economic University, Ternopil, Ukraine, n.kolomyichuk@tneu.edu.ua

ORCID ID: 0000-0001-6160-9053

\section{METHODS OF TEACHING FINANCIAL LITERACY IN HIGHER EDUCATION: EXPERIENCE AND PROSPECTS}

Introduction. An integral condition for determining the role of educational factors in the process of forming the financial worldview of citizens is the development and testing of effective and efficient methods of teaching financial literacy. At the same time, there is currently no single methodological approach to the teaching of financial literacy in educational institutions of Ukraine, which requires intensification of scientific efforts aimed at studying the above problem.

The purpose is to systematize the experience of teaching financial literacy in higher education and highlight the prospects for its improvement in modern conditions of development of the domestic educational space.

Methods. Methods of dialectical analysis and synthesis, as well as methods of logical generalization, comparison and formalization are used in the reseach. 
Results. The newest methods of teaching financial literacy are studied, the features and advantages of each of them are highlighted and the positive effects they cause are emphasized, namely: promoting the development of theoretical thinking and cognitive interest in financial literacy; activation of perception of material in the process of teaching the basics of financial literacy; providing professional motivation and formation of corporate culture in students when studying the discipline "Methods of teaching financial literacy". A number of scientific and pedagogical events organized and conducted at Ternopil National Economic University together with teachers of secondary, vocational and higher educational institutions are analyzed in order to discuss the vectors of improving the current methods of teaching financial literacy. The necessity of using innovative tools in teaching financial literacy in domestic educational institutions is substantiated and the directions of increasing the level of financial literacy of Ukrainians in modern conditions are suggested.

Perspectives. Further research is proposed to focus on identifying the main vectors of increasing the level of financial literacy of children and youth, as the most potentially favorable for this segment of Ukrainian society. In our opinion, this will provide an opportunity to form a holistic system of measures to overcome the sometimes indifferent attitude of young Ukrainians to their future financial well-being.

Keywords: financial literacy, methods of teaching financial literacy, case method, training, business game, problem lecture, lecture-visualization, binary lecture, lecture with pre-planned mistakes, lecture-press conference

JEL Classification: 015.

Постановка проблеми. В умовах сьогодення питання підвищення рівня фрінансової грамотності населення $€$ актуальним для усіх країн світу. Фінансова криза, зростаюча заборгованість, недостатня обізнаність населення щодо різноманітних фінансових послуг, нездатність громадян приймати раціональні фрінансові рішення та жити відповідно до власних доходів змусили уряди більшості країн розробляти і впроваджувати державні програми з підвищення рівня фрінансової грамотності для населення. Це і не дивно, адже фінансовий ринок нині розвивається настільки стрімко, продукуючи величезні масиви фрінансової інформації, що більшість пересічних громадян не встигають її ґрунтовно осмислити. А економічний розвиток держави, як відомо, напряму залежить від рівня фрінансової грамотності та фрінансової обізнаності населення. Відтак, якщо рівень знань грома- дян про фрінансову сферу є низьким, то від цього страждає увесь сектор економіки та держава загалом [1, с. 631-632].

Тому у сучасних умовах розширення використання фрінансових послуг, ускладнення і появи нових фінансових інструментів, питання фрінансової грамотності населення стають надзвичайно актуальними, а забезпечення особистої фрінансової безпеки громадян $є$ важливим фактором формування економічного добробуту населення зокрема та держави загалом.

Відтак активізація досліджень проблем підвищення рівня фінансової грамотності в Україні зумовлюють необхідність системного впровадження новітніх науково-методичних розробок у практику фрінансової освіти, яка $є$ одним із чинників фрінансової соціалізації суспільства, що надзвичайно важливо в сучасних умовах стрімкого розвитку глобальних фрінансових технологій. 
Аналіз останніх досліджень і публікацій. Дослідженням проблем розвитку особистих (сімейних) фрінансів та фрінансової грамотності населення займалися зарубіжні науковці: Г. Беккер, Ш. Данс, Е. Ларсон, А. Лусарді, Т. Хіра, Г. Шахназарян [2] та ін. Окремі вектори формування фрінансової грамотності населення, як одного із пріоритетів сучасної державної політики, відображені у працях українських науковців: Н. Барадії [3], О. Дудчик [1], А. Кузнєцової [4], Г. Кучерової, Т. Латковської [5], І. Матвійчук [1], І. Можарівської [6], Л. Покась [3], М. Тимошенко [6], В. Письменного [7], Л. Ребухи [7], Т. Смовженко [4] та ін. Однак базові компоненти сучасної методики викладання фінансової грамотності у закладах освіти України та практичні аспекти їх реалізації залишаються не повною мірою дослідженими, що свідчить про актуальність та практичну значимість дослідження.

Метою статті $є$ систематизація досвіду викладання фінансової грамотності у вищій школі та виокремлення перспектив його удосконалення в сучасних умовах розвитку українського освітянського простору.

Виклад основного матеріалу дослідження. Модернізація системи вищої освіти в Україні потребує впровадження новітніх форм викладання фрінансової грамотності, як важливого чинника фрінансової соціалізації українського суспільства, використання інноваційних технологій навчання та осучаснення методів навчального процесу. Адже науково обґрунтована та якісно продумана методика викладання фрінансової грамотності впливає, насамперед, на підвищення рівня фрінансової грамотності студентів та забезпечує єдність інтересів викладача і студентів у процесі вивчення дисципліни.

Безперечно, завдання підвищення рівня фрінансової грамотності населення нині $€$ одним із найбільш актуальних для урядів, громадських організацій та освітянської спільноти різних держав. У багатьох країнах світу (зокрема, США, Великій Британії, Канаді, Австралії, Франції, ФРН, Швеції, Австрії, Сінгапурі, Індії, Польщі) функціонують різноманітні державні програми підвищення рівня фрінансової грамотності населення. Вони значно різняться між собою, проте переслідують одну мету - сприяють зростанню фрінансової активності населення та подальшому розвитку національних економік.

Слід акцентувати, що упродовж останніх десятиліть світовою спільнотою накопичено значний досвід щодо розробки та впровадження ефективних програм фрінансової освіти та підвищення рівня фрінансової грамотності. Причому досвід зарубіжних країн переконливо доводить, що проблеми захисту прав споживачів фрінансових послуг та довіри населення до фрінансового сектору постають практично перед усіма державами світу [5, с. 429]. Відтак зазначимо, що нині слід зважено підходити до вирішення питань доцільності, форм і специфіки використання зарубіжних напрацювань та 3 урахуванням національних особливостей адаптувати існуючі методики і продукти у вітчизняну практику, розробляти власні і формувати національні методико-педагогічні ресурси для розвитку фрінансової освіти в Україні.

Важливо наголосити, що упродовж останніх років у педагогічній практиці вітчизняних закладів вищої освіти, крім традиційних методів викладання фрінансової грамотності, значного поширення набули й інноваційні методики [3, с. 93]. Зокрема, широко використовують активні методи навчання - інтерактивні лекції (залежно від способу викладу навчального матеріалу), кейс-методи, тренінги, ділові ігри тощо.

Так, надзвичайно популярними у викладанні фрінансової грамотності (причому як се- 
ред студентів, так і викладачів) є проблемні лекції, лекції-візуалізації, бінарні лекції, лекції із заздалегідь запланованими помилками, лекції-пресконференції [7, с. 190-192]. Скажімо, на проблемних лекціях викладач фрормулює проблемну ситуацію, пов'язану із будь-яким аспектом фрінансової грамотності, та спонукає студентів до пошуку шляхів ії вирішення. Безумовно, такі лекції сприяють розвитку теоретичного мислення, пізнавального інтересу до прикладних аспектів фрінансової грамотності, забезпечують професійну мотивацію та формування корпоративної культури у студентів.

Лекцію-візуалізацію використовують 3 метою пошуку нових можливостей для реалізації принципу наочності при викладанні фінансової грамотності. Зокрема, викладач застосовує демонстраційні матеріали, інші форми наочності, що не лише доповнюють словесну інформацію, а й самі $€$ носіями змістовної інформації. Тобто, підготовка візуальної лекції передбачає "перекодування” змісту лекції або ії частини у візуальну форму для подання ії̈ студентам через технічні засоби. Причому у візуальній лекції дуже важливі візуальна логіка та ритм подачі матеріалу, його дозування, майстерність і стиль спілкування викладача з аудиторією.

Бінарна лекція $€$ розвитком проблемного викладу матеріалу в діалозі двох викладачів (або викладача і практика), на якій моделюють реальні ситуації, пов'язані із підвищенням рівня фрінансової грамотності, а також обговорюють теоретичні і практичні питання двоє фахівців. Перевагами такої лекції $€$ актуалізація наявних у студентів знань з фінансової грамотності, необхідних для розуміння діалогу та участі у ньому; створення проблемної ситуації; розгортання системи доведення.

Доволі цікавими у педагогічній практиці $€$ лекції із заздалегідь запланованими по- милками, що передбачають визначену кількість типових помилок змістового, методичного чи поведінкового характеру. Тому такі лекції одночасно виконують стимулюючу, контрольну і діагностичну функції.

Важливою також $є$ лекція-пресконференція, на якій викладач пропонує студентам письмово поставити йому запитання із проанонсованої теми. Причому практичний досвід переконує, що такі лекції доцільно проводити: на початку вивчення курсу (для виявлення інтересів групи або потоку, їх установок та можливостей); в середині курсу (для залучення студентів до ключових моментів вивчення дисципліни "Методика викладання фінансової грамотності" і систематизації отримуваних знань); у кінці для визначення перспектив розвитку засвоєного матеріалу.

Слід акцентувати, що одним із ефективних методів навчання, який широко використовують у Тернопільському національному економічному університеті в процесі викладання фінансової грамотності, $€$ case study. Кейс-метод - це метод навчання на основі аналізу реальної фрінансової ситуації, що містить у собі спеціалізований навчальний матеріал, який охоплює кейс (текстовий опис подій), інструкцію щодо роботи з цим кейсом, рекомендації з використання кейсу та спеціальну технологію використання пропонованого матеріалу в процесі навчання. Серед переваг case study виокремимо: застосування базових принципів проблемного навчання; отримання студентами навичок роботи в команді; набуття досвіду презентації результатів роботи; уміння фрормулювати питання й аргументувати відповідь. Важливим $€$ те, що реалізація кейс-методу пов'язана з використанням у процесі викладання фрінансової грамотності моделювання, системного аналізу, проблемного й ігрового методів, уявного експерименту, а також методів 
опису і класифікації, кожен із яких відіграє в кейс-методі вагому роль.

Тренінг, як форма організації заняття 3 фінансової грамотності, сприяє інтенсивності навчання, результат якого досягається завдяки активній роботі кожного з його учасників, адже знання під час тренінгу стають продуктом активної взаємодії його учасників [9, с. 164]. При цьому, за умови чіткої організації й дотримання методики проведення, такі заняття: сприяють розвитку творчого мислення, фрормуванню практичних умінь та навичок у студентів; стимулюють і підвищують інтерес до нових знань, активізують сприйняття матеріалу; створюють позитивний мікроклімат в колективі, творчу й доброзичливу атмосфреру; підвищують якість навчального процесу та підготовки студентів.

Ділові ігри в процесі проведення практичних занять із фрінансової грамотності дають змогу моделювати складні життєві ситуації, пов'язані з управлінням особистими фрінансами, сприяють розвитку фінансового мислення. У ході ділової гри студенти вчаться виробляти власну стратегію фрінансової поведінки, розвивати інтуїцію, складати фрінансові прогнози, аргументувати власні висновки. Ігрові моменти підвищують інтерес студентів до базових компонент фрінансової грамотності, вчать працювати в команді, формують почуття відповідальності за спільне рішення чи успішність проекту.

Однак варто наголосити, що теоретичні знання, подані викладачем та здобуті студентами в аудиторії, повною мірою засвоюються лише тоді, коли вони будуть апробовані на практиці. Тож з метою удосконалення методики викладання фрінансової грамотності у Тернопільському національному економічному університеті було організовано та проведено, спільно з педагогами загальноосвітніх, професійних та вищих навчальних закладів, низку цікавих і пізнавальних науково-педагогічних заходів із вищеозначеної тематики.

Зокрема, у квітні 2017 р. на базі ТНЕУ відбувся Перший освітній форум "Упровадження курсу “Фінансова грамотність" в навчально-виховний процес у контексті змін сучасної освіти". Метою заходу був обмін досвідом у сорері викладання дисципліни “Фінансова грамотність”, а також розширення рівня компетенції вчителів у сорері управління особистими фрінансами, формування відповідальної фрінансової поведінки та прийняття обґрунтованих фрінансових рішень. Учасники фроруму проаналізували досвід викладання фрінансової грамотності у загальноосвітніх навчальних закладах та вишах Тернопільської області, окреслили його науково-методичний супровід, провели тренінг "Фінансові піраміди: вид шахрайства чи спосіб заробітку?”, виокремили позитивні та проблемні моменти впровадження курсу “Фінансова грамотність”, також його основні тенденції у контексті змін сучасної освіти.

Другий регіональний освітній форум "Особливості впровадження курсу "Фінансова грамотність” у контексті модернізації освітнього процесу", проведений на базі Тернопільського національного економічного університету спільно з Тернопільським обласним комунальним інститутом післядипломної педагогічної освіти 18 квітня 2018 р., дав можливість учасникам подискутувати щодо особливостей методики грамотного складання сімейного бюджету, витрачання коштів, способів заощаджень у різних життєвих ситуаціях, представити досвід реалізації студентського стартапу "Від А до Я", а також низку інших проектів, спрямованих на підвищення компетенції молоді в управлінні особистими фрінансами.

Безумовно, методика викладання фрінансової грамотності передбачає та відтво- 
рює основні фрорми передачі фрінансовоекономічних знань фрахівцями 3 провідних галузей фрінансової науки та практики. Відтак, 16 березня 2018 р. в рамках святкування Всесвітнього тижня грошей (Global money week) в ТНЕУ було проведено круглий стіл на тему: "Взаємодія освітян, влади і громадськості у підвищенні фрінансової грамотності молоді Тернопілля". Цей захід забезпечив можливість висвітлення актуальних питань фінансової освіти, ії̈ популяризації серед молоді та участі у цьому процесі представників влади, освітян і громадських діячів.

У сучасних умовах фрінансова грамотність визначає рівень життя громадян, сприяє подоланню бідності, зниженню економічних ризиків суб'єктів підприємництва та фрізичних осіб $[10$, с. 6]. Такі реалії вимагають адекватної реакції освітянського простору на запити сьогодення. 3 цією метою 9 листопада 2018 р. на базі ТНЕУ, спільно з Тернопільським обласним комунальним інститутом післядипломної педагогічної освіти, було проведено вернісаж-практикум для педагогів Тернопільської області “Проект "Фінансова грамотність" у контексті реформування освіти”. Учасники узагальнили сучасні практики викладання фрінансової грамотності у контексті проблемно-орієнтованого навчання, поділилися досвідом написання книг і створення мультфрільмів для дітей з фінансової грамотності, виокремили основні вектори підвищення рівня фрінансової грамотності сучасної молоді. В рамках заходу учні загальноосвітніх шкіл та студенти коледжів взяли участь у квесті “Фінансове розслідування”, зіграли у гру "Alias: Financial Edition" та відвідали музей історії ТНЕУ і музей історії грошей.

Важливо наголосити, що удосконалення методики викладання фінансової грамотності допомагає студентам зрозуміти сутність ключових фрінансових понять, а також успішно застосовувати їх у процесі: ухвалення рішень про доходи, витрати та заощадження; вибору оптимальних фрінансових інструментів для інвестування; планування бюджету; накопичення коштів на майбутні цілі тощо. У контексті вищезазначеного, 9 квітня 2019 р. у ТНЕУ був проведений Третій регіональний освітній фрорум з методики викладання фрінансової грамотності, на якому були презентовані навчальні програми та просвітницькі проекти, спрямовані на підвищення компетенції молоді в процесі управління особистими фінансами, а також визначено перспективи підвищення кваліфрікації вчителів щодо запровадження інноваційних освітніх технологій і методів навчання у сфрері фрінансової грамотності. Для учнів загальноосвітніх шкіл був організований networking "Як навчитися заощаджувати гроші?”, тренінг “Фінансове шахрайство - небезпечна зброя сьогодення" та воркшоп "Мій особистий бюджет".

3 метою популяризації фрінансової грамотності серед молоді 21 жовтня 2019 р. Тернопільський національний економічний університет організував для учнів, студентів коледжів і вчителів Тернопільської, Львівської і Хмельницької областей II Всеукраїнський вернісаж-практикум “Тиждень фрінансової грамотності. Прев'ю”, учасники якого обговорили можливості та перспективи підвищення кваліфікації освітян 3 фрінансової грамотності. У рамках вернісажу-практикуму було презентовано настільні фрінансові ігри для дітей: "Банківська картка”, “Малі підприємці”, “Мій перший мільйон”, “Дитячий бюджет”, “Вірю не вірю", "Знайти фрінансового шахрая" та "Квест в магазині". Водночас для учнів і студентів коледжів студентами, які навчаються на магістерській освітньо-професійній програмі “Фінансова грамотність”, було проведено низку заходів, спрямованих на отримання нових знань і практичних навичок у 
сфрері фрінансової грамотності. Так, учасники інтелектуального конкурсу “Фінансовий ерудит” обґрунтовували можливі напрями витрачання коштів та вказували пріоритети власного вибору за умови гіпотетичного отримання 1 млн грн. При цьому ідеї учнів вирізнялися креативністю, оригінальністю та новизною підходу. У грі “Доходи-витрати” команди учасників змагалися за першість у формуванні найбільш оптимального сімейного бюджету. Проведена гра "Alias: financial edition" передбачала синонімічне пояснення фінансових термінів. Для наймолодших учасників вернісажу-практикуму були проведені рухливі ігри на фрінансову тематику.

Необхідно констатувати, що через низький рівень фрінансової грамотності та відсутність елементарних навичок управління особистими фінансами значна частина населення України виявилася непідготовленою до життя в умовах карантинних заходів, спричинених пандемією, пов'язаною із COVID-19. При цьому режим дистанційного навчання став неабияким викликом для педагогів, учнів і студентів. Відтак саме питання специфіки викладання фінансової грамотності в умовах он-лайн навчання були розглянуті на Четвертому он-лайн-форумі з методики викладання фінансової грамотності, організованому професорсько-викладацьким колективом кафедри фінансів імені С.І. Юрія ТНЕУ 6 липня 2020 р. у режимі zoom-конференції. Цей захід об'єднав педагогів із різних регіонів України, які виокремили найпомітніші зміни у сфрері особистих фінансів, спричинені епідеміологічною ситуацією, та вказали на можливості удосконалення методики викладання фінансової грамотності за таких умов.

У нинішніх реаліях з метою удосконалення викладання фрінансової грамотності доцільним вважаємо якомога ширше залучення фахівців-практиків для ґрунтовнішо- го розуміння студентами сучасних тенденцій, що відбуваються у фрінансовій сфері України, і сприяння втіленню креативних ідей студентства у практичну діяльність. Це, безумовно, стимулюватиме підприємницькі ініціативи студентів і у майбутньому допомагатиме їм у відкритті власної справи чи реалізації власного проекту. Скажімо, у ТНЕУ уже $є$ позитивний досвід такої діяльності, коли переможець конкурсу студентських стартапів - проект "Кіно без меж” (створення тифлокоментарів до україномовних фрільмів та організація їх показу для незрячих людей) - був реалізований у м. Тернополі у 2019 р. за безпосередньої й активної участі студентів та за кошти “Громадського бюджету Тернополя".

Доцільним у сучасних умовах також вважаємо ширше використання у процесі викладання фрінансової грамотності такого новаційного педагогічного методу як коучинг, що передбачає: системний супровід зростання студента, спрямований на ефективне досягнення важливих для нього цілей у чітко визначені терміни; партнерську комунікативну співпрацю; розкриття потенціалу студента для досягнення максимального результату; супровід студента, що дасть змогу переміститися йому із зони проблеми в зону ефективного її вирішення; підтримка студента за індивідуальною освітньою траєкторією.

Висновки. Таким чином, підсумовуючи вищевикладене, зазначимо, що:

1) у світовій практиці викладання фрінансової грамотності набуло стрімкого поширення в освітніх закладах, що, відповідним чином, позитивно відобразилося на високому рівні розвитку національних економік таких країн;

2) в Україні методика викладання фрінансової грамотності постійно удосконалюється відповідно до реалій 
сьогодення та зважаючи на сучасні світові тренди, свідченням чому $€$ тривалий практичний досвід такого викладання у Тернопільському національному економічному університеті;

3) нині необхідно проводити якомога більше заходів з підвищення рівня фрінансової грамотності населення, насамперед дітей та молоді, в основу яких має бути закладено не лише інформування, а й розвиток практичних умінь і навичок [4, с. 34-35]. Поряд із цим, слід впроваджувати державні програми щодо популяризації фрінансової грамотності, надавати доступ до фрінансової освіти усім верствам населення, організувати консультативні групи з розроблення навчальних матеріалів для вивчення фрінансової грамотності в українських освітніх закладах різного рівня.

Також надзвичайно актуальною у нинішніх реаліях $€$ необхідність впровадження інтерактивних методів навчання у фінансову освіту, які передбачають застосування новітніх навчальних методик із використанням сучасних електронних та інтернеттехнологій, активне залучення до освітньої діяльності з фрінансової грамотності засобів масової інформації, використання соціальних мереж, розробка спеціалізованих вебсайтів для розвитку навичок з фрінансових питань для якомога більшого охоплення ними усіх верств населення.

\section{Список використаних джерел}

1. Дудчик О. Ю., Матвійчук І. О., Фінансова грамотність: теоретичні аспекти, проблеми i перспективи поліпшення в Україні. Інфраструктура ринку. 2019. № 31. С. 631-635.

2. Шахназарян Г. Э. Финансовая грамотность населения в свете современных тен- денций развития образования. Финансы и креdum. 2011. № 20 (308). С. 51-58.

3. Барадія Н., Покась Л. Формування фрінансової грамотності через впровадження педагогічних технологій. Актуальні питання гуманітарних наук. 2019. Вип. 23. Том 1. C. 89-94.

4. Смовженко Т. С., Кузнєцова А. Я. Фінансова грамотність населення та їі вплив на розвиток економіки України. Регіональна економіка. 2013. № 2(68). С. 34-42.

5. Латковська Т. А. Підвищення рівня фрінансової грамотності. Наукові праці Національного університету "Одеська юридична академія". 2013. T. 13. C. 429-438. URL : http://nbuv.gov.ual UJRN/Nponyua_2013_13_45.

6. Тимошенко М. М., Можарівська І. М. Організація та методика викладання дисциплін економічних спеціальностей. Профресійно-прикладні дидактики. 2016. Вип. 1. С. 159-167.

7. Кізима Т. О., Ребуха Л. З., Письменний В. В., Коваль С. Л. та ін. Методика викладання фрінансової грамотності : навчальний посібник / за ред. д.е.н., профресора Т.О. Кізими, д.пед.н., доцента Л. З. Ребухи : 2 вид., перероб. і доп. Тернопіль : Економічна думка, 2020. 220 с.

8. Фінансова грамотність, обізнаність та інклюзія в Україні: звіт про дослідження. Додатковий проект IP-FSS в Україні. Проект регіонального економічного розвитку. 2017. 69 c. URL : https://bank.gov.ua/doccatalog/ document?id=83136332.

\section{References}

1. Dudchyk, O. I., Matviichuk, I. O. (2019). Finansova hramotnist: teoretychni aspekty, problemy i perspektyvy polipshennia v Ukraini [Financial literacy: theoretical aspects, problems and prospects for improvement in Ukraine]. Infrastruktura rynku Market Infrastructure, 31, 631-635 [in Ukrainian].

2. Shahnazaryan, G. E. (2010). Finansovaya gramotnost naseleniya $v$ svete sovremennyih tendentsiy razvitiya obrazovaniya [Financial literacy of the population in the light of current trends in 
education]. Finansy i kredit - Finance and Credit, 20 (308), 51-58 [in Russian].

3. Baradiia, N., Pokas, L. (2019). Formuvannia finansovoi hramotnosti cherez vprovadzhennia pedahohichnykh tekhnolohiy [Formation of financial literacy through the introduction of pedagogical technologies]. Aktualni pytannia humanitarnykh nauk - Current Issues of the Humanities, 23(1), 89-94 [in Ukrainian].

4. Smovzhenko, T.S., Kuznietsova, A.Y. (2013). Financial literacy of the population and its impact on the development of Ukraine's economy [Financial literacy of the population and its impact on the development of Ukrainian economy]. Rehionalna ekonomika - Regional Economy, 2 (68), 34-42 [in Ukrainian].

5. Latkovska, T. A. (2013). Pidvyshchennia rivnia finansovoi hramotnosti [Increasing the level of financial literacy]. Naukovi pratsi Natsionalnoho universytetu "Odeska yurydychna akademiia" Scientific Works of the National University "Odessa Law Academy". Available at: http://nbuv.gov.ual UJRN/Nponyua $2013 \quad 13 \quad 45$.
6. Tymoshenko, M.M., Mozharivska, I.M. (2016). Orhanizatsiia ta metodyka vykladannia dystsyplin ekonomichnykh spetsialnostei [Organization and methods of teaching economic specialties]. Profesiino-prykladni dydaktyky - Professional and Applied Didactics, 1, 159-167 [in Ukrainian].

7. Kizyma, T.O., Rebuha, L.Z., Pysmennyi, V.V., Koval, S.L. (2019). Metodyka vykladannia finansovoi hramotnosti [Methods of teaching financial literacy]. (2nd ed., rev.). Ternopil: Ekonomichna dumka [in Ukrainian].

8. Finansova hramotnist, obiznanist ta inkliuziia v Ukraini: zvit pro doslidzhennia. Dodatkovyi proekt IP-FSS v Ukraini. Proekt rehionalnoho ekonomichnoho rozvytku [Financial literacy, awareness and inclusion in Ukraine: a research report. Additional IP-FSS project in Ukraine. Regional Economic Development Project]. Available at: https://bank.gov. ua/doccatalog/document?id=83136332.

Стаття надійшла до редакції 02.04.2020. 